\title{
Fish welfare: an NGO's point of view
}

\author{
Elena Lara \\ Research Manager -Fish \\ Compassion in World Farming, United Kingdom \\ Natasha Boyland \\ Fish Policy and Research Manager \\ Compassion in World Farming, United Kingdom
}

Received: October 2019

Accepted: November 2019

Recommended citation. LARA, E., BOYLAND, N., Fish welfare: an NGO's point of view, dA. Derecho Animal (Forum of Animal Law Studies) 10/4 (2019) - DOI https://doi.org/10.5565/rev/da.462

\begin{abstract}
Fish are the most exploited, forgotten and misunderstood animals on the planet. They also are extraordinary creatures: complex, intelligent, sensitive, curious, and some of them have amazing abilities. For instance; some use tools, have a good memory, or collaborate to hunt. And most importantly, they are sentient, and they feel pain. Aquaculture has become the main supplier of fish worldwide, accounting for just over half of the fish eaten by humans due to static global wild-capture stocks, which have been overfished for decades. Also, global consumption of fish has doubled since the early 1970s and will continue to grow with population growth in the developing world. However, the aquaculture industry has developed without proper consideration of the needs of the fish species farmed, and the welfare consequences for those animals. Moreover, the rapid growth of aquaculture has raises major sustainability concerns due to its continued reliance on wild-caught fish. Annually, 0.5-1.0 trillion fish are caught to be reduced to ingredients to feed farmed animals, mainly fish. When considering the negative environmental consequences of using wild-caught fish as feed, we must not overlook the huge animal welfare impact that represents for the huge number of animals involved. Compassion in World Farming is working to raise awareness about fish sentience and the welfare problems that aquaculture industry represents for fish welfare. The way that fish are treated is important and we must do it better.
\end{abstract}

Keywords: fish welfare, fish sentience, aquaculture, fishmeal and fish oil.

Resumen - Bienestar en peces: la perspectiva de defensa de los animales

Los peces son los animales más explotados, olvidados e incomprendidos del planeta. Pero también son criaturas extraordinarias: complejos, inteligentes, sensibles, curiosos, y algunos de ellos tienen habilidades increíbles. Por ejemplo, algunos usan herramientas, tienen buena memoria o colaboran para cazar. Pero lo más importante es que los peces son seres sintientes y por lo tanto sienten dolor. La acuicultura se ha convertido en el principal proveedor de pescado en todo el mundo; más de la mitad del pescado que consumimos es cultivado. Esto se debe principalmente a que las capturas de peces salvajes se han estabilizado porque han estado sobreexplotadas durante décadas. Además, el consumo mundial de pescado se ha duplicado desde principios de la década de los 70 y continuará creciendo con el aumento de la población. Sin embargo, la industria de la acuicultura se ha desarrollado sin el debido conocimiento de las necesidades de las especies de peces cultivadas y las consecuencias para el bienestar de estos animales. Asimismo, el rápido crecimiento de la acuicultura ha generado importantes preocupaciones a nivel medio ambiental ya que esta industria depende de las capturas de peces salvajes. Anualmente, se capturan 0.5-1.0 billones de peces para ser transformados en ingredientes para alimentar a los animales de granja, principalmente peces. Al considerar las consecuencias ambientales negativas del uso de peces salvajes como alimento, no debemos pasar por alto el enorme impacto que supone a nivel de bienestar animal ya que el 
número de animales involucrados es muy alto. Compassion in World Farming trabaja para crear conciencia de que los peces son animales sintientes y los problemas de bienestar que la industria acuícola representa para los peces. La forma en que tratamos a los peces es importante y debemos hacerlo mejor.

Palabras clave: bienestar en peces, sintiencia, acuicultura, harina de pescado y aceite de pescado.

\section{Introduction}

Compassion in World Farming (CIWF) is an international animal welfare environmentalist charity. It was funded in 1967 by Peter Roberts, a British dairy farmer who could see first-hand how the demand for "cheap" food was having devastating effect on farm animals, the environment and humans. CIWF focuses on ending factory farming because animal welfare should be a priority in agriculture, and this is not possible with intensive systems. CIWF is working to transform our current food system into one that does not involve cruelty and does not destroy our planet. To achieve these objectives, CIWF is campaigning to strengthen animal welfare legislation, persuading global food companies to produce only higher animal welfare products and exposing the true impacts of factory farming - from animal suffering to environmental pollution, damage to human health and the devastation of our wildlife.

Around the world, up to 2.3 trillion fish are caught from the wild, and up to 167 billion are farmed for human consumption ${ }^{1}$. Of the wild fish captured globally each year, $0.5-1.0$ trillion are caught specifically to feed to farm animals ${ }^{2}$, mostly farmed fish. These wild fish will be reduced to fishmeal and fish oil (FMFO) to produce ingredients for fish feeds. This has allowed the huge growth of intensive aquaculture over the past few decades, an industry that has developed without a proper understanding of the welfare needs of the fish species farmed. Furthermore, most farmed fish are killed without pre-stunning, and suffer slow, painful deaths.

Two years ago, CIWF started a new project focused on fish welfare which has significant potential impact since, of all the animal groups used by humans, fish are by far the greatest in numbers. Fish welfare is gaining more prominence in industry, science and policy, but currently there is much work to be done to ensure that the mental, physical and behavioural need of fish are met in aquaculture. In this rapidly expanding sector welfare impacts on the farmed species are expected, however there are also far reaching impacts on wild animals. In this article, we describe current knowledge of fish sentience and cognition, some key challenges for farmed fish, and present the hidden link to wild fish welfare and ramifications for marine ecosystems.

\section{Fish sentience and cognition}

Historically there has been relatively little public concern regarding fish welfare, suggesting a lack of understanding and/or empathy for these animals ${ }^{3}$. Part of the problem seems to be the large communication gap between fish and humans, since we live in different environments which restricts human-fish contact ${ }^{4}$. Fish have unfamiliar body language, have senses that we lack, have no facial expressions that we can understand, and do not make sounds perceivable by the human ear ${ }^{5}$. Therefore, fish do not possess the physical or social characteristics to elicit human empathy or compassion in the way that most other vertebrates $\mathrm{do}^{6}$. However, our understanding and perception of fish is progressing. Scientific evidence demonstrates that fish are sentient animals; they are aware of the external environment and of their own internal emotional states, with the ability to experience pleasure, pain and other emotions ${ }^{7}$.

\footnotetext{
1 MOOD, A., BROOKE, P., Fish number estimates based on FAO 2017 data, according to methods published on https://fishcount.org.uk (2017).

${ }^{2}$ Ibid.

${ }^{3}$ LUND, V., MEJDELL, C. M., RÖCKLINSBERG, H., ANTHONY, R., HÅSTEIN, T. Expanding the moral circle: Farmed fish as objects of moral concern. Diseases of Aquatic Organisms, 75 (2007) 109-118.

${ }^{4}$ BROWN, C. Fish intelligence, sentience and ethics. Anim. Cogn. (2014). doi:10.1007/s10071-014-0761-0

${ }^{5}$ DRIESSEN, C. P. G. In awe of fish? Exploring animal ethics for non-cuddly species. Consum. Everyday Life (2018) 257-282 doi:10.4324/9781315660691-11

${ }^{6}$ BROWN, C. Fish intelligence, sentience and ethics. Anim. Cogn. (2014). doi:10.1007/s10071-014-0761-0

7 ASHLEY, P. J. et al. Effect of noxious stimulation upon antipredator responses and dominance status in rainbow trout. Anim. Behav, 77 (2009) 403-410; BRAITHWAITE, V. A., HUNTINGFORD, F. A. Fish and welfare: Do fish have the capacity for pain perception and suffering? Anim. Welf. 13 (2004) 87-92; BROWN, C. Comparative evolutionary approach to pain perception in fishes. Anim. Sentience 011 (2016) 1-7; BSHARY, R., GINGINS, S., VAIL, A. L. Social cognition in fishes. Trends Cogn. Sci. 18 (2014) 465-471; CHANDROO, K., DUNCAN, I. J., MOCCIA, R. Can fish suffer?: perspectives on sentience, pain, fear and stress. Appl. Anim. Behav. Sci. 86 (2004) 225-250; SNEDDON, L. U. The evidence for pain in fish: The use of morphine as an analgesic. 
Fish are also more intelligent than we give them credit for ${ }^{8}$. Recent scientific publications document numerous sophisticated behaviours. For example, fish are able to integrate information and have good longterm memories that allow them to learn tasks, problem solve, use tools, cooperate, have numerical skills, navigate long distances and learn through watching others 9 .

Unlike cognitive abilities, what animals feel is more difficult, or even impossible, to measure ${ }^{10}$. We cannot know what is happening inside another animal's mind, even when that animal is another human ${ }^{11}$. Presently, we must rely on brain anatomical traits, and physiological and behavioural responses to identify the capacity for sentience ${ }^{12}$. Teleost (bony) fish have the hardware for pain perception ${ }^{13}$; they have the necessary receptors (nociceptors) and nerve fibres to detect painful events ${ }^{14}$. Also, they respond to pain relief, e.g. morphine. In fact, they have an opioid system that works in a similar way to mammals ${ }^{15}$. Not just a reflexive system, fish respond to painful stimuli with physiological and behavioural responses that suggest an emotional and longer-term response ${ }^{16}$. For example, when trout were injected with bee venom or vinegar, their breathing rate increases, stress hormones are released, they lose their appetite and interest in their surroundings, and they appear to focus on the area of the body that has been injured ${ }^{17}$. Higher order cognitive processes such as attention or spatial awareness are significantly altered by the painful stimuli ${ }^{18}$. This demonstrates that fish respond to aversive events and they alter their subsequent behaviour. Despite the evidence mentioned above, there is still controversy surrounding fish pain. The deniers' main claim is that fish cannot feel pain because they do not possess brain structures believed to be essential to conscious pain in mammals, specifically regions of the neocortex and mesocortex. They state that fish show reflexive responses only, and that they are incapable of true cognitive abilities ${ }^{19}$. However, fish have the necessary receptors and nerve fibres to detect painful events and their brains are arranged in a similar structure to mammal brains, with the exception of the neocortex which developed in mammals. Brains of different animals have evolved to do similar things in slightly different ways or using different structures. Another example of this is that in mammals' vision is processed in the 'cortex', but in fish and reptiles' vision is processed in the optic lobe, and yet all of these animals can achieve the same end goal - they can see. Indeed, according to Braithwaite "there is as much evidence that fish feel pain and suffer as there is for birds and mammals" 20 . In any case, there is certainly enough evidence to give fish the benefit of the doubt and treat them with care. It is therefore important that we urgently address fish welfare issues in aquaculture.

\section{Farmed fish}

Most of the 51-167 billion fish ${ }^{21}$ produced in farms are reared in intensive systems ${ }^{22}$, where fish are kept at high stocking densities in barren environments - a set up tailored to maximise production rather than

Appl. Anim. Behav. Sci. 83 (2003) 153-162; FRANKS, B., SEBO, J., HOROWITZ, A. Fish are smart and feel pain: What about joy? Commentary on Sneddon et al. on Sentience Denial. Anim. Sentience 156 (2018) 1-4

8 BROWN, C. Fish intelligence, sentience and ethics. Anim. Cogn. (2014). doi:10.1007/s10071-014-0761-0; BATZINA, A., DALLA, C., TSOPELAKOS, A., PAPADOPOULOU-DAIFOTI, Z., KARAKATSOULI, N. Environmental enrichment induces changes in brain monoamine levels in gilthead seabream Sparus aurata. Physiol. Behav, 130 (2014) 85-90

9 AGRILlO, C., MILETTO PETRAZZINI, M. E., BISAZZA, A. Numerical abilities in fish: A methodological review. Behav. Processes, 141 (2017)161-171; DE LUCA, G., MARIANI, P., MACKENZIE, B. R., MARSILI, M. Fishing out collective memory of migratory schools. J. R. Soc. Interface 11 (2014) 20140043; HANSEN, L. P., JONSSON, N., JONSSON, B. Oceanic migration in homing Atlantic salmon. Anim. Behav. 45 (1993) 927-941; JONES, A. M., BROWN, C., GARDNER, S. Tool use in the tuskfish Choerodon schoenleinii? Coral Reefs 30 (2011) 865; KAWASE, H., OKATA, Y., ITO, K. Role of huge geometric circular structures in the reproduction of a marine pufferfish. Sci. Rep. 3 (2013) 2106; KOHDA, M. et al. Cleaner wrasse pass the mark test. What are the implications for consciousness and self-awareness testing in animals? bioRxiv (2018); SALWICZEK, L. H. et al. Adult Cleaner Wrasse Outperform Capuchin Monkeys, Chimpanzees and Orang-utans in a Complex Foraging Task Derived from Cleaner - Client Reef Fish Cooperation. PLoS One 7 (2012).

${ }^{10}$ BROWN, C. Fish intelligence, sentience and ethics. Anim. Cogn. (2014). doi:10.1007/s10071-014-0761-0

${ }^{11}$ Ibid.

12 Ibid.

${ }^{13}$ SNEDDON, L. U. Anatomical and electrophysiological analysis of the trigeminal nerve in a teleost fish, Oncorhynchus mykiss. Neurosci. Lett. 319 (2002)167-171

${ }^{14}$ Ibid.

${ }^{15}$ SNEDDON, L. U. The evidence for pain in fish: The use of morphine as an analgesic. Appl. Anim. Behav. Sci. 83 (2003) $153-162$

${ }^{16}$ SNEDDON, L. U. Pain in aquatic animals. J. Exp. Biol. 218 (2015) 967-976

${ }^{17}$ SNEDDON, L. U. The evidence for pain in fish: The use of morphine as an analgesic. Appl. Anim. Behav. Sci. 83 (2003) $153-162$

${ }^{18}$ CHANDROO, K., DUNCAN, I. J., MOCCIA, R. Can fish suffer?: perspectives on sentience, pain, fear and stress. Appl. Anim. Behav. Sci. 86 (2004) 225-250

${ }^{19}$ ROSE, J. D. et al. Can fish really feel pain? Fish Fish. 15 (2012) 97-133 doi:10.1111/faf.12010

${ }^{20}$ BRAITHWAITE, V. A. Do fish feel pain? (Oxford University Press, 2010).

21 MOOD, A., BROOKE, P. Fish number estimates based on FAO 2017 data, according to methods published on https://fishcount.org.uk (2017)

${ }^{22}$ FAO (Food and Agriculture Organization of the United Nations). World Fisheries and Aquaculture (2018). 
fish welfare. As for many farmed animals, welfare needs must be met to some extent to achieve good productivity ${ }^{23}$. However, this is usually measured on a group level rather than an individual one (i.e. some individuals may suffer more and there can be a relatively high mortality rate, providing that the system remains economical) and often focus is on the physical health, and less on meeting the mental and behavioural needs of the animal ${ }^{24}$.

In intensive aquaculture fish can suffer from higher rates of acute and chronic stress, aggression and injuries, and with this the risk of disease transmission increases ${ }^{25}$ - similar features and problems to those commonly referred to as 'factory farms' for terrestrial animals. Fish are often exposed to extremely stressful handling procedures, involving being taken out of the water where they experience asphyxia, and the vast majority of fish farmed around the globe are killed using inhumane slaughter practices ${ }^{26}$.

Commonly, fish are killed by asphyxiation in air or ice slurry, or exposure to carbon dioxide gas; loss of consciousness and death by these methods is not quick, and suffering is unacceptably prolonged ${ }^{27}$. Alternatively, they may die during the process of gutting and processing ${ }^{28}$. Fish are legally recognized as sentient beings according to the Treaty on the Functioning of the European Union (2012). The Council regulation 1099/2009 on the protection of animals at the time of killing states that " animals shall be spared any avoidable pain, distress or suffering during their killing and related operations", and this statement applies to fish. Therefore, fish should be stunned before being killed to avoid pain and suffering. Stunning methods (such as electrical or percussive stunning) are available and can allow for a more humane death for some species, but there is a significant amount of work required to achieve widespread industry adoption. Other problems that the aquaculture industry should deal with are greenhouse gas emissions ${ }^{29}$, deleterious impacts on wild fish populations from farmed fish escapes (European Comission, 2015), antibiotic and chemical use or abuse ${ }^{30}$, nutrient release from waste feed and faeces that impact the marine environment, and slavery ${ }^{31}$.

\section{Wild-caught fish, fishmeal and fish oil}

When considering the negative effects of fish farming, we should not overlook the hidden layer of animal welfare problems: the welfare of wild-caught fish destined for fish feed which fuels aquaculture (and other farmed animals $)^{32}$. That is, the impact of farming carnivorous species ${ }^{33}$. Besides the welfare issues regarding method of production of the farmed fish, we should not disassociate the other fish and marine animals involved in the supply chain ${ }^{34}$. In order to feed many farmed fish species, huge numbers of fish are caught from the wild to be made into feed for farmed fish. 'Reduction fisheries' catch fish and crustaceans (mainly krill) to make fishmeal and fish oil (FMFO), which are the main animal protein ingredients of feeds used for aquaculture and agriculture ${ }^{35}$. Therefore, when assessing the animal welfare impacts of aquaculture, we must include both the farmed fish and the numerous wild-caught fish connected with producing it. We calculated that for the production of one farmed salmon, up to 350 wild-caught fish are used as feed, and so the welfare of those individuals must also be considered ${ }^{36}$. The vast majority of fish caught from the wild

\footnotetext{
23 SARAiVA, J.L., CASTANHEIRA, M.F., ARECHAVAlA-LOPEZ, P., VOLSTORF, J., HEINZPETER STUDER, B. Domestication and Welfare in Farmed Fish. In Animal Domestication; IntechOpen: London, UK (2018).

${ }^{24}$ Ibid.

${ }^{25}$ ASHLEY, P. J. Fish welfare: Current issues in aquaculture. Appl. Anim. Behav. Sci. 104 (2007) 199-235

${ }^{26}$ Compassion in World Farming. The welfare of farmed fish during slaughter in the European union. (2018).

${ }^{27}$ Ibid.

${ }^{28}$ Ibid.

${ }^{29}$ TACON, A. G. J. Demand and supply of feed ingredients for farmed fish and crustaceans: trends and prospects. FAO Fisheries and Aquaculture Technical Paper No. 564. FAO, 2011. 87

${ }^{30}$ TACON, A. G. J. Demand and supply of feed ingredients for farmed fish and crustaceans: trends and prospects. FAO Fisheries and Aquaculture Technical Paper No. 564. FAO, 2011. 87; ROMERO, J., GLORIA, C., NAVARRETE, P. Antibiotics in Aquaculture - Use, Abuse and Alternatives. Health and Environment in Aquaculture (2012). doi:10.5772/28157

${ }^{31}$ NAYLOR, R., BURKE, M. Aquaculture and ocean resources: raising tigers of the sea. Annu. Rev. Environ. Resour. 30 (2005) 185-218; TICKLER, D. et al. Modern slavery and the race to fish. Nat. Commun. 9 (2018) 4643

${ }^{32}$ NAYLOR, R., BURKE, M. Aquaculture and ocean resources: raising tigers of the sea. Annu. Rev. Environ. Resour. 30 (2005) 185-218; NAYLOR, R. L. et al. Feeding aquaculture in an era of finite resources. Proc. Natl. Acad. Sci. U. S. A. 106 (2009) 1510310

${ }^{33}$ ALDER, J., CAMPBELL, B., KARPOUZI, V., KASCHNER, K., PAULY, D. Forage Fish: From Ecosystems to Markets Further Annual Reviews. (2008). doi:10.1146/annurev.environ.33.020807.143204; CASHION, T., LE MANACH, F., ZELLER, D., PAULY, D. Most fish destined for fishmeal production are food-grade fish. Fish Fish. 18 (2017) 837-844

${ }^{34}$ ALDER, J., CAMPBELL, B., KARPOUZI, V., KASCHNER, K., PAULY, D. Forage Fish: From Ecosystems to Markets Further Annual Reviews. (2008). doi:10.1146/annurev.environ.33.020807.143204

${ }^{35}$ Ibid.

${ }^{36}$ BYElashOV, O. A., GRIFFIN, M. E. Fish In, Fish Out: Perception of Sustainability and Contribution to Public Health. Fisheries 39 (2014) 531-535; YTRESTØYL, T., AAS, T. S., ÅSGÅRD, T. Utilisation of feed resources in production of Atlantic 
suffer immensely during the processes of catching, landing and killing ${ }^{37}$. Industrial fishing methods catch fish in huge numbers at a time. When hundreds of thousands of fish are caught - for example, in a purse seine net or trawling net - they are intensely crowded during capture, then packed tightly together as they are hauled to the surface of the water. Fish will be damaged (e.g. physical abrasions, compression, bursting of internal organs due to sudden pressure changes) and stressed during this process. A significant proportion will die, crushed under the weight of other fish in the nets. For fish that survive capture and landing (being brought aboard the vessel), there is usually no slaughter method; they are simply left to asphyxiate or may die during processing ${ }^{38}$. Marine mammals and birds may also be caught up in these practices, becoming bycatch and dying slow deaths, or being injured during capture and release $\mathrm{e}^{39}$.

There is also a knock-on effect on marine ecosystems. The fish destined for reduction to FMFO are mainly low trophic level species, plankton feeders that form dense schools. These are often referred to as "forage fish" which includes anchovy, sardine, herring, mackerel, etc ${ }^{40}$. These species play a key role in the marine environment because they transfer energy from primary producers to higher trophic levels such as larger fish, marine mammals and seabirds ${ }^{41}$. Thus, overfishing down food webs can have important ecological impacts for the ecosystem function ${ }^{42}$. While FMFO is generally sourced from reduction fisheries, it also includes fish trimmings and fish is also used directly for feed from by-catch of non-selective fisheries as shrimp trawls ${ }^{43}$. That said, based on FAO fisheries capture tonnages, it is estimated that $0.5-1$ trillion fish are caught each year only to be reduced to ingredients to feed farmed animals, mainly fish ${ }^{44}$.

The use of FMFO is supporting the rise of intensive aquaculture which is driven by a growing demand for fish of specific species, mainly carnivorous (e.g. salmon, trout, sea bass, sea bream), that are preferred by consumers in developed countries ${ }^{45}$. On the other hand, many farmed herbivorous species that don't require fish inputs in their feed are increasingly being supplemented with FMFO, or whole fish, to speed up growth ${ }^{46}$. Therefore, the increase in global aquaculture is compromising the future of forage-fish populations, which play a key role in the marine environment, while animal welfare in fish farms remains a major problem. Fortunately, the concept of farmed fish welfare and its importance is starting to gain attention in research, policy and the media. However, the hidden layer to this animal welfare crisis - the welfare of wild-caught fish destined for fish feed - is often overlooked. Together, these industries lead to immense suffering for a huge number of animals.

\section{Proposed improvements}

The current food system has become a consumer good, more focused on low prices than in the way that is produced and the true cost of food origin. CIWF believes that we need to move forward to a sustainable and humane food system for people, animals and the environment; a regenerative production system without the cruelty of factory farming. CIWF encourages people to eat less animal products (moderate to low or none) and eat more fresh fruits and vegetables, which is more beneficial to health and the environment than diets heavy in meat, fish, diary, etc ${ }^{47}$.

People who do choose to eat fish may want to look at both sustainability issues and animal welfare.

salmon (Salmo salar) in Norway. Aquaculture 448 (2015) 365-374

${ }^{37}$ METCALFE, J. D. Welfare in wild-capture marine fisheries. J. Fish Biol. 75 (2009) 2855-2861

${ }^{38}$ VELDHUIZEN, L. J. L., BERENTSEN, P. B. M., DE BOER, I. J. M., VAN DE VIS, J. W., BOKKERS, E. A. M. Fish welfare in capture fisheries: A review of injuries and mortality. Fish. Res. 204 (2018) 41-48

${ }^{39}$ LEWISON, R. L., CROWDER, L. B., READ, A. J., FREEMAN, S. A. Understanding impacts of fisheries bycatch on marine megafauna. Trends in Ecology and Evolution 19 (2004) 598-604

${ }^{40}$ ALDER, J., CAMPBELL, B., KARPOUZI, V., KASCHNER, K., PAULY, D. Forage Fish: From Ecosystems to Markets Further Annual Reviews. (2008). doi:10.1146/annurev.environ.33.020807.143204

${ }^{41}$ Ibid.

${ }^{42}$ NAYLOR, R. L. et al. Feeding aquaculture in an era of finite resources. Proc. Natl. Acad. Sci. U. S. A. 106 (2009) 15103-10; ESSINGTON, T. E. et al. Fishing amplifies forage fish population collapses. Proc. Natl. Acad. Sci. U. S. A. 112 (2015) 6648-52; NAYLOR, R. L. et al. Effect of aquaculture on world fish supplies. Nature 405 (2000) 1017-1024; SMITH, A. D. M. et al. Impacts of fishing low-trophic level species on marine ecosystems. Science 333 (2011) 1147-50

${ }^{43}$ HUNTINGTON, T., HASAN, M. R. Fish as feed inputs for aquaculture - practices, sustainability and implications: a global synthesis. In M.R. Hasan and M. Halwart (eds). Fish as feed inputs for aquaculture: practices, sustainability and implications. FAO Fisheries and Aquaculture Technical Paper. No. 518. Rome, FAO. pp. 1-61 (2009).

44 MOOD, A., BROOKE, P., Fish number estimates based on FAO 2017 data, according to methods published on https://fishcount.org.uk (2017)

${ }^{45}$ EUMOFA. The EU Fish Market. (2017).

${ }^{46}$ TACON, A. G. J., METIAN, M. Global overview on the use of fish meal and fish oil in industrially compounded aquafeeds: Trends and future prospects. Aquaculture 285 (2008) 146-158

${ }^{47}$ HILBORN, R., BANOBI, J., HALL, S. J., PUCYLOWSKI, T., WALSWORTH, T. E. The environmental cost of animal source foods. Front. Ecol. Environ. 16 (2018) 329-335 
As a general rule, it may be useful to suggest that people who choose to eat farmed fish to avoid carnivorous fish since huge number of wild-caught fish is used to produce fish feeds. We recommend consuming farmed fish that do not require animal protein in their feed as carp or tilapia. Currently, it is virtually impossible to find "high welfare" fish since inhumane slaughter of fish remains common across the industry. However, some certification schemes have some welfare standards for fish as GlobalGap or BAP. Thus, we encourage consumers to pay attention to fish labels and choose products certified by these schemes. Also, fish produced in extensive or organic production systems are generally reared in better conditions than intensive fish farms as they can be closer to natural environments. For that people who choose wild-caught fish, fish products certified by schemes that ensures sustainable fisheries is recommended (however this does not mean anything for welfare) and it is always better to buy local fish from a small, non-industrial operation.

\section{Conclusions}

Here, we have aimed to describe the most important and detrimental issues of fish welfare. The lack of information about fish sentience and cognition resulting in a poor human empathy or compassion has built one of the most important animal welfare problems: the poor value that humans give to fish and therefore, the treatment that they receive from us. A shift in consumer and industry perception of fish is needed to push welfare standards up. Also, research and technical development is needed to meet the wellbeing requirements of the fish. The way forward consists of several steps, which include education, research, transparency from the aquaculture industry, commitment of policies, laws and codes and animal welfare assurance from certification schemes for consumers. Compassion in World Farming is working to spread the message of fish sentience to the general public, consumers, scientists and the whole fish industry because attitudes to fish and the ways that they are treated are important. The numbers of animals affected is huge but also, they are sentient, intelligent and conscious animals and thus capable of suffering. They deserve the same recognition and protection as other groups of animals. It's time to Rethink fish.

\section{References}

- Agrillo, C., Miletto PetrazZINI, M. E., BISAZZA, A. Numerical abilities in fish: A methodological review. Behav. Processes, 141 (2017)161-171

- ALDER, J., CAMPBELL, B., KARPOUZI, V., KASCHNER, K., PAULY, D. Forage Fish: From Ecosystems to Markets Further Annual Reviews. (2008). doi:10.1146/annurev.environ.33.020807.143204

- ASHLEY, P. J. Fish welfare: Current issues in aquaculture. Appl. Anim. Behav. Sci. 104 (2007) 199-235

- ASHLEY, P. J. et al. Effect of noxious stimulation upon antipredator responses and dominance status in rainbow trout. Anim. Behav, 77 (2009) 403-410

- BATZINA, A., DAlla, C., TSOPElAKOS, A., PAPADOPOUlOU-DAIFOTI, Z., KARAKATSOULI, N., Environmental enrichment induces changes in brain monoamine levels in gilthead seabream Sparus aurata. Physiol. Behav, 130 (2014) 85-90

- BRAITHWAITE, V. A., HUNTINGFORD, F. A. Fish and welfare: Do fish have the capacity for pain perception and suffering? Anim. Welf. 13 (2004) 87-92

- BRAITHWAITE, V. A. Do fish feel pain? (Oxford University Press, 2010).

- BROWN, C., Fish intelligence, sentience and ethics. Anim. Cogn. (2014).

- doi:10.1007/s10071-014-0761-0

- BROWN, C. Comparative evolutionary approach to pain perception in fishes. Anim. Sentience 011 (2016) $1-7$

- BSHARY, R., GINGINS, S., VAIL, A. L. Social cognition in fishes. Trends Cogn. Sci. 18 (2014) 465-471

- BYelashov, O. A., GRIFFIN, M. E. Fish In, Fish Out: Perception of Sustainability and Contribution to Public Health. Fisheries 39 (2014) 531-535

- CASHION, T., LE MANACH, F., ZELLER, D., PAULY, D. Most fish destined for fishmeal production are food-grade fish. Fish Fish. 18 (2017) 837-844

- CHANDROO, K., DUNCAN, I. J., MOCCIA, R. Can fish suffer?: perspectives on sentience, pain, fear and stress. Appl. Anim. Behav. Sci. 86 (2004) 225-250

- Compassion in World Farming. The welfare of farmed fish during slaughter in the European union. (2018). 
- DE LUCA, G., MARIANI, P., MACKENZIE, B. R., MARSILI, M. Fishing out collective memory of migratory schools. J. R. Soc. Interface 11 (2014) 20140043

- DRIESSEN, C. P. G., In awe of fish? Exploring animal ethics for non-cuddly species. Consum. Everyday Life (2018) 257-282 doi:10.4324/9781315660691-11

- EUMOFA. The EU Fish Market. (2017).

- ESSINGTON, T. E. et al. Fishing amplifies forage fish population collapses. Proc. Natl. Acad. Sci. U. S. A. 112 (2015) 6648-52

- FAO (Food and Agriculture Organization of the United Nations). World Fisheries and Aquaculture (2018).

- FRANKS, B., SEBO, J., HOROWITZ, A., Fish are smart and feel pain: What about joy? Commentary on Sneddon et al. on Sentience Denial. Anim. Sentience 156 (2018) 1-4

- HANSEN, L. P., JONSSON, N., JONSSON, B. Oceanic migration in homing Atlantic salmon. Anim. Behav. 45 (1993) 927-941

- HILBORN, R., BANOBI, J., HALl, S. J., PUCYlOWSKI, T., WALSWORTH, T. E. The environmental cost of animal source foods. Front. Ecol. Environ. 16 (2018) 329-335

- HUNTINGTON, T., HASAN, M. R. Fish as feed inputs for aquaculture - practices, sustainability and implications: a global synthesis. In M.R. Hasan and M. Halwart (eds). Fish as feed inputs for aquaculture: practices, sustainability and implications. FAO Fisheries and Aquaculture Technical Paper. No. 518. Rome, FAO. pp. 1-61 (2009).

- JONES, A. M., BROWN, C., GARDNER, S. Tool use in the tuskfish Choerodon schoenleinii? Coral Reefs 30 (2011) 865

- KAWASE, H., OKATA, Y., ITO, K. Role of huge geometric circular structures in the reproduction of a marine pufferfish. Sci. Rep. 3 (2013) 2106

- KOHDA, M. et al. Cleaner wrasse pass the mark test. What are the implications for consciousness and self-awareness testing in animals? bioRxiv (2018).

- LEWISON, R. L., CROWDER, L. B., READ, A. J., FREEMAN, S. A. Understanding impacts of fisheries bycatch on marine megafauna. Trends in Ecology and Evolution 19 (2004) 598-604

- LUND, V., MEJDELL, C. M., RÖCKLINSBERG, H., ANTHONY, R., HÅSTEIN, T. Expanding the moral circle: Farmed fish as objects of moral concern. Diseases of Aquatic Organisms, 75 (2007) 109-118

- METCALFE, J. D. Welfare in wild-capture marine fisheries. J. Fish Biol. 75 (2009) 2855-2861

- MOOD, A., BROOKE, P., Fish number estimates based on FAO 2017 data, according to methods published on https://fishcount.org.uk (2017)

- NAYLOR, R. L. et al. Effect of aquaculture on world fish supplies. Nature 405 (2000) 1017-1024

- NAYLOR, R., BURKE, M. Aquaculture and ocean resources: raising tigers of the sea. Annu. Rev. Environ. Resour. 30 (2005) 185-218

- NAYLOR, R. L. et al. Feeding aquaculture in an era of finite resources. Proc. Natl. Acad. Sci. U. S. A. 106 (2009) 15103-10

- ROMERO, J., GlORIA, C., NAVARRETE, P. Antibiotics in Aquaculture - Use, Abuse and Alternatives. Health and Environment in Aquaculture (2012). doi:10.5772/28157

- ROSE, J. D. et al. Can fish really feel pain? Fish Fish. 15 (2012) 97-133 doi:10.1111/faf.12010

- SALWICZEK, L. H. et al. Adult Cleaner Wrasse Outperform Capuchin Monkeys, Chimpanzees and Orang-utans in a Complex Foraging Task Derived from Cleaner - Client Reef Fish Cooperation. PLoS One, 7 (2012).

- SARAIVA, J.L., CASTANHEIRA, M.F., ARECHAVALA-LOPEZ, P., VOLSTORF, J., HEINZPETER STUDER, B. Domestication and Welfare in Farmed Fish. In Animal Domestication; IntechOpen: London, UK (2018).

- SMITH, A. D. M. et al. Impacts of fishing low-trophic level species on marine ecosystems. Science 333 (2011) 1147-50

- SNEDDON, L. U. Anatomical and electrophysiological analysis of the trigeminal nerve in a teleost fish, Oncorhynchus mykiss. Neurosci. Lett., 319 (2002)167-171

- SNEDDON, L. U. The evidence for pain in fish: The use of morphine as an analgesic. Appl. Anim. Behav. Sci. 83 (2003) 153-162

- SNEDDON, L. U. Pain in aquatic animals. J. Exp. Biol. 218 (2015) 967-976

- TACON, A. G. J. \& METIAN, M. Global overview on the use of fish meal and fish oil in industrially compounded aquafeeds: Trends and future prospects. Aquaculture 285 (2008) 146- 
158

- TACON, A. G. J. Demand and supply of feed ingredients for farmed fish and crustaceans: trends and prospects. FAO Fisheries and Aquaculture Technical Paper No. 564. FAO, 2011. 87

- TICKLER, D. et al. Modern slavery and the race to fish. Nat. Commun. 9 (2018) 4643

- VeldhuizEN, L. J. L., BERENTSEN, P. B. M., DE BOER, I. J. M., VAN DE VIS, J. W., BOKKERS, E. A. M. Fish welfare in capture fisheries: A review of injuries and mortality. Fish. Res. 204 (2018) 41-48

- YTRESTØYL, T., AAS, T. S., ÅSGÅRD, T. Utilisation of feed resources in production of Atlantic salmon (Salmo salar) in Norway. Aquaculture 448 (2015) 365-374 